\title{
The hepatitis $C$ epidemic in Canada: An overview of recent trends in surveillance, injection drug use, harm reduction and treatment
}

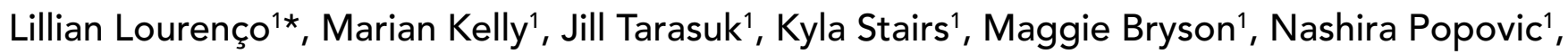 \\ Josephine Aho'
}

\begin{abstract}
Hepatitis $C$ continues to be a significant public health concern in Canada, with the hepatitis $C$ virus $(\mathrm{HCV})$ responsible for more life-years lost than all other infectious diseases in Canada. An increase in reported hepatitis $C$ infections was observed between 2014 and 2018. Here, we present changing epidemiological trends and discuss risk factors for hepatitis $\mathrm{C}$ acquisition in Canada that may have contributed to this increase in reported hepatitis $C$ infections, focusing on injection drug use. We describe a decrease in the use of borrowed needles or syringes coupled with an increase in using other used injection drug use equipment. Also, an increased prevalence of injection drug use and use of prescription opioid and methamphetamine injection by people who inject drugs (PWID) may be increasing the risk of HCV acquisition. At the same time, while harm reduction coverage appears to have increased in Canada in recent years, gaps in access and coverage remain. We also consider how direct-acting antiviral (DAA) eligibility expansion may have affected hepatitis $C$ rates from 2014 to 2018. Finally, we present new surveillance trends observed in 2019 and discuss how the coronavirus disease 2019 (COVID-19) pandemic may affect hepatitis $C$ case counts from 2020 onwards. Continual efforts to i) enhance hepatitis $C$ surveillance and ii) strengthen the reach, effectiveness, and adoption of hepatitis $C$ prevention and treatment services across Canada are vital to reducing HCV transmission among PWID and achieving Canada's HCV elimination targets by 2030.
\end{abstract}

This work is licensed under a Creative Commons Attribution 4.0 Internationa License.

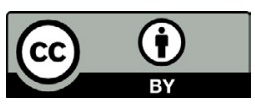

Affiliation

${ }^{1}$ Public Health Agency of Canada, Centre for Communicable Diseases and Infection Control, Ottawa, ON

*Correspondence:

lillian.lourenco@phac-aspc.gc.ca

Suggested citation: Lourenço L, Kelly M, Tarasuk J, Stairs K, Bryson M, Popovic N, Aho J. The hepatitis C epidemic in Canada: an overview of recent trends in surveillance, injection drug use, harm reduction and treatment. Can Commun Dis Rep 2021;47(12):561-70. https://doi.org/10.14745/ccdr.v47i12a01

Keywords: HCV, epidemiology, people who inject drugs, PWID, needle-and-syringe programs, supervised consumption, Canadian Drugs and Substances Strategy, substance use

\section{Introduction}

Hepatitis $C$ is a preventable and, in almost all cases, curable liver infection. Despite this, hepatitis $C$ is responsible for more life-years lost than any other infectious disease in Canada (1-3). Researchers estimate that, in 2017, at least one person was infected with the hepatitis $\mathrm{C}$ virus (HCV) every hour in Canada, and 194,500 Canadians were living with chronic hepatitis $C$ (4). In June 2018, the federal, provincial and territorial ministers of health released the Pan-Canadian Sexually Transmitted and Blood-borne Infections Framework for Action (5). The Framework endorses the World Health Organization's target to eliminate viral hepatitis as a public health threat by 2030 , including achieving a $90 \%$ reduction in new cases of chronic hepatitis $C$ infections by 2030 (5).

Hepatitis $C$ is a nationally notifiable disease monitored by the Public Health Agency of Canada (PHAC). The Agency reports annually on trends in reported hepatitis $C$ cases overall and by age, sex and province or territory. Surveillance data show a $14 \%$ increase in the reported national hepatitis $C$ rate, from 29.4 per 100,000 people in 2014 to 33.6 per 100,000 people in 2018 (6), representing a total of acute, chronic and unspecified hepatitis $C$ cases. In addition, from 2014 to 2018, the reported hepatitis C rates increased faster for females than for males (20\% vs $10 \%$ increase) (6).

This article summarizes several trends and factors that may have influenced the rising hepatitis C rates between 2014 and 2018. While several factors are associated with the risk of hepatitis $C$ acquisition, injection drug use is the most common risk factor for new infections in Canada (7-9). In this overview, we describe changes in injection drug use patterns and practices as well as in harm reduction services and practices. We also consider the impact-recent and potential-of expanding direct-acting antiviral (DAA) eligibility on hepatitis $C$ rates. Finally, we discuss 
surveillance trends from 2018 to 2019 and the potential impact of the coronavirus disease 2019 (COVID-19) pandemic on the hepatitis $\mathrm{C}$ epidemic in Canada.

\section{A changing landscape: Injection drug use on the rise}

An estimated $1 \%$ of Canada's population have ever injected drugs (10) and about $0.3 \%$ were using injection drugs in 2014 (11). PHAC estimated that people who inject drugs (PWID) made up almost half of those who ever had a hepatitis C infection in 2017 (4). Based on data from 2000 to 2016, PWID make up between $60 \%$ and $85 \%$ of all new HCV infections in Canada (7-9). The sharing of needles, syringes and other injection equipment appears to be the primary driver of $\mathrm{HCV}$ transmission in Canada today (7-9). A modelling study estimated that the PWID population in Canada increased by $32 \%$ between 2011 and 2016 (11).

\section{Injection drug use, social determinants of health and key populations}

Injection drug use is associated with a history of trauma and family instability $(12,13)$, transactional sex $(12,13)$, food insecurity $(14,15)$, incarceration $(12,16)$, insecure housing $(12,17-23)$, low income $(12,17,20,24)$, lower levels of education (12), systemic discrimination $(12,24)$ and unemployment $(21,23,25)$.

Indigenous peoples bear a disproportionate burden of substance use disorders and associated harms in Canada, a situation that is associated with structural injustices rooted in colonization. Available evidence suggests Indigenous peoples are overrepresented among PWID in several regions in Canada (12,26-29). Estimates show that Indigenous youth (aged 24 years and younger) make up between $70 \%$ and $80 \%$ of new HCV infections among young PWID in Canada (30-32).

Gay, bisexual and other men who have sex with men (gbMSM) are an emerging population at risk for hepatitis $C(33,34)$. An estimated $5 \%$ of gbMSM have a past or current $\mathrm{HCV}$ infection (35). Injection drug use appears to be the leading risk factor for hepatitis $C$ in this population in Canada (33), though sexual transmission in the context of certain sexual practices associated with a risk of exposure via blood has also been known to occur, particularly among gbMSM living with HIV (36-38).

Understanding evolving behaviours related to $\mathrm{HCV}$ acquisition is essential to understanding the evolving hepatitis $C$ epidemic among PWID.

\section{Increased prevalence of prescription opioid injection and methamphetamine use among people who inject drugs}

Substance use patterns in North America have been described in terms of "twin epidemics," comprising the opioid crisis, which has been responsible for a significant burden of morbidity and mortality among PWID in Canada over the past two decades (39), and an apparent resurgence of psychostimulant use and related harms since 2017 (40). In the most recent bio-behavioural Tracks survey of PWID in Canada (Phase 4: 2017-2019), the five most frequently reported injected drugs (in the six months before the survey) were cocaine (60.0\%), hydromorphone $(50.1 \%)$, methamphetamine $(43.5 \%)$, morphine $(41.6 \%)$ and heroin $(32.4 \%)$. Of note, hydromorphone, morphine and heroin are all opioids (12).

Although national prevalence estimates are not available, non-medical use of prescription opioids has become increasingly common among PWID in Canada over the past 15 years (41-43). One study from Montréal found that in a prospective cohort of PWID, the proportion reporting prescription opioid injection increased from $21 \%$ in 2004 to $75 \%$ in 2009 . PWID who reported prescription opioid injection were more likely than PWID who were non-prescription opioid injection drug users to acquire hepatitis $C$ (41). This increased risk may be in part due to more frequent injections and increased opportunities for sharing used injection equipment $(42,44)$ among those who use prescription opioids, a cohort that tends to be younger and less experienced with injection drug use (41).

The prescription opioid epidemic may be accelerating the transition to injection drug use among younger people who use drugs (45). Several studies from the United States have found an association between the increasing use of injection prescription opioids and increased rates of hepatitis $C$ infections, particularly among younger adults ( $<30$ years old) and reproductive-aged females (46-48).

There has also been a reported increase in the prevalence of methamphetamine use in Canada over the past 15 years $(12,49,50)$. In the Tracks survey of PWID in Canada, the proportion of participants injecting methamphetamine increased from 6.8\% in Phase 1 (2003-2005) to 43.5\% in Phase 4 (2017-2019) (12). Methamphetamine use has been associated with HCV transmission in Canadian studies $(51,52)$ and linked to increased frequency of syringe sharing (53) and increased injection frequency (54). Rates of methamphetamine use vary widely across the country (50). The most pronounced increases appear to be in Western and Central Canada $(50,55,56)$. In 2016, the Winnipeg region declared a hepatitis $C$ outbreak linked to a dramatic increase in the use of methamphetamine (57-59). 


\section{Injection drug use equipment sharing practices are changing}

The proportion of Tracks survey participants who reported borrowing used needles or syringes decreased from $20.2 \%$ in Phase 1 (2003-2005) to 11.6\% in Phase 4 (2017-2019) (12). In contrast, the proportion of participants who reported borrowing other used injection equipment (water, filters, cookers, spoons, tourniquets, ties, swabs and acidifiers) increased by almost one-third between Phase 1 and 4 (from 29.8\% to 38.0\%) (12). This finding is a concern as the risk of HCV acquisition from sharing drug-preparation equipment is similar to that associated with syringe sharing (60) and persists in the absence of needle or syringe sharing (61). Some studies have linked prescription opioid injection use to increased sharing of other used injection equipment, specifically, the sharing of "washes" (the residue found on used filters and cookers) (42,61-63).

\section{Harm reduction coverage across Canada is increasing, but gaps remain}

In 2016, the federal minister of health announced an updated drug strategy for Canada, the Canadian Drugs and Substances Strategy (CDSS) $(64,65)$. The CDSS puts an increased emphasis on public health in the Government of Canada's response to substance use, with harm reduction included as one of the pillars of the strategy in addition to prevention, treatment and enforcement $(64,65)$. Increased federal action and investments to address substance use, overdose prevention, addictions, harm reduction and drug treatment followed the launch of the CDSS. In 2017, PHAC created the Harm Reduction Fund, one of the CDSS initiatives (66), to support community-based projects across Canada that help reduce HIV and hepatitis $C$ acquisition and transmission among people who share injection and inhalation drug use equipment. Evidence-based harm reduction strategies, such as needle-and-syringe programs, opioid agonist therapy and supervised consumption services are essential to reducing the risk of $\mathrm{HCV}$ transmission and reinfection among PWID $(67,68)$. The Phase 4 (2017-2019) Tracks survey of PWID found that $90.1 \%$ of participants reported using a needle-andsyringe distribution program, $47.3 \%$ used some form of opioid agonist therapy and $13.5 \%$ used a supervised consumption service in the 12 months before the survey (12).

One Canadian modelling study found that between 2011 and 2016, needle-and-syringe coverage increased from 193 to 291 needles and syringes per PWID (11). Opioid-agonist-therapy coverage increased from 55 to 66 recipients per 100 PWID, despite increasing injection drug use over this period (11). Based on these preliminary data, Canada appears to be meeting the World Health Organization's needle-and-syringe-program and opioid-agonist-therapy provision targets overall. However, coverage and access vary across provinces and territories $(11,33)$.

\section{Hepatitis $\mathrm{C}$ rates among females in Canada are on the rise}

From 2014 to 2018, reported hepatitis $C$ rates increased for both females and males (6). However, while rates were consistently higher among males, rates for females in 2018 were $20 \%$ higher than those in 2014; while rates for males were $10 \%$ higher. Also, women aged 25 to 39 years old showed the largest hepatitis $C$ rate increases in Manitoba, Ontario, Québec, New Brunswick and Yukon during this time. Similarly, during the same period, higher rate increases of other sexually transmitted and bloodborne infections (STBBI), such as syphilis and HIV, were reported among females compared to males in several jurisdictions $(69,70)$. Several studies from the United States have also reported an increase in hepatitis $C$ rates among reproductive-age females in recent years, a trend that has been linked to the opioid crisis (46-48).

While the bio-behavioural surveillance data from Phase 4 of the Tracks survey of PWID found that the proportion who self-reported borrowing other used injecting equipment in the past six months was $45.9 \%$ for cisgender females versus $33.7 \%$ for cisgender males (12), understanding what is driving these increasing rates among females is challenging for three main reasons: i) national routine surveillance data do not include risk factor data; ii) no testing volume data are available; and iii) Canadian research to contextualize this trend is limited.

\section{Low hepatitis $C$ treatment rates, expansion of direct-acting antivirals and its potential impact on future hepatitis $C$ rates among the people who inject drugs community}

According to the 2017-2019 PWID Tracks survey, 10.6\% of PWID who were aware of their hepatitis $C$ infection had ever taken hepatitis $C$ treatment and $3.8 \%$ were currently receiving treatment (12). Low treatment rates are of concern for the health of the individual living with hepatitis $C$ and the potential risk for HCV transmission.

There is substantial evidence demonstrating that PWID, including those with ongoing substance use, can be successfully treated for hepatitis $C$ (71-73) particularly when treatment is delivered in a low-barrier setting and paired with wrap-around social and harm reduction supports (74-77). Moreover, Canadian modelling studies show that treatment can act as prevention in high-prevalence groups, such as PWID, especially when combined with opioid agonist therapy and high-coverage needle-and-syringe programs $(78,79)$.

From 2014 to early 2018, Canadian hepatitis C treatment guidelines limited second-generation DAAs (with cure rates above $95 \%$ against the main HCV genotypes) to people with advanced liver fibrosis or cirrhosis (80). In June 2018, the 
Canadian guidelines removed all disease-stage restrictions on DAA eligibility, making DAAs eligible for all people with chronic hepatitis $C$ (81). However, the rollout of lifting disease-stage restrictions differed by province and territory, and other non-disease-stage restrictions remain and differ by province and territory $(82,83)$. Although it is likely that expanded DAA eligibility may have contributed to an increase in hepatitis $C$ testing across Canada from 2014 to 2018, there is, unfortunately, a lack of Canadian scientific evidence to support this hypothesis.

A study by Saeed et al. found that while hepatitis $C$ treatment uptake increased dramatically among PWID after treatment restrictions were lifted in British Columbia, Ontario and Québec, uptake rates declined a year later (83). This was thought to reflect a "warehousing effect," as physicians began clearing the initial backlog of treatment-eligible individuals engaged in care who had been deferring treatment until DAAs became available (83). To this end, we need innovative and tailored programs and policies to successfully engage PWID in care and facilitate increased levels of treatment initiation (33,83-87).

The advent of DAAs has raised concerns about a potentially higher risk of reinfection in high-risk populations, such as PWID and HIV-positive gbMSM $(88,89)$. However, concurrent harm reduction strategies and behavioural and structural interventions appear to reduce the risk of reinfection $(72,74,77,90,91)$. The impact of DAA on treatment uptake and reinfection risk are both areas that warrant further scholarly attention and surveillance.

\section{Anticipating the impact of the COVID-19 pandemic on hepatitis $C$ in Canada}

Evidence is already emerging that the COVID-19 pandemic and public health mitigation measures have adversely impacted the delivery of and demand for STBBI prevention, testing, treatment and harm reduction services in Canada (92). According to a 2020 PHAC survey of how the COVID-19 pandemic impacted the delivery of STBBI and harm reduction services in Canada, 21\% of service providers providing support and treatment services for people living with HIV, hepatitis C or both experienced a decreased demand for and ability to deliver their services (92). In addition, $44 \%$ of STBBI prevention, testing and treatment service providers experienced a decrease in their ability to provide their services. Concurrently, $40 \%$ of harm reduction and drug treatment service providers reported an increase in demand for their services, although $63 \%$ reported no change or only a slight change in their ability to deliver their services (92). Given decreased access to HCV testing, this will likely impact the number of HCV diagnoses in 2020 and 2021, generating in underestimating the rate of newly reported hepatitis $C$ cases. This would occur in the context of changing drug use practices generating from the pandemic's impact on harm reduction service availability and the quality and quantity of the drug supply, and COVID-related isolation requirements (93-97).
Conversely, the COVID-19 pandemic may generate in new opportunities for engagement in hepatitis $C$ care. The same survey noted that $81 \%$ of STBBI-related service providers provided remote services since the beginning of the pandemic. Of these, $66 \%$ created new remote services during this period (92). The recent expansion of virtual care, if sustained, may present opportunities to improve access to hepatitis $\mathrm{C}$ care in the future, particularly for rural and remote populations $(92,93,98)$, and could reduce wait times for accessing specialty care (99), enabling faster treatment scale-up. However, future monitoring and research will be needed to determine whether such virtual services have high uptake among PWID.

At the time of going to press, the latest available hepatitis $C$ surveillance data showed the national reported hepatitis $C$ rate had declined by 10\% from 2018 to 2019 (100). Furthermore, all but two provinces and territories showed declining reported hepatitis $C$ rates, of between $-4 \%$ and $-40 \%$ (Prince Edward Island's hepatitis $C$ rates increased by $15 \%$ since 2018, and Nova Scotia's remained stable). Unfortunately, due to the impacts of the COVID-19 pandemic, it will be difficult to determine if the rate drop from 2018 to 2019 should be interpreted as a blip or a new trend.

\section{Discussion}

This overview article summarized several changing trends and risk factors associated with hepatitis $C$, with a strong focus on injection drug use practices. These trends and risk factors may partially explain the rising reported hepatitis $C$ rates observed in Canada between 2014 and 2018. We also discussed how the staggered expansion of DAA eligibility across Canada may have contributed to an increase in hepatitis $C$ testing and how this and the COVID-19 pandemic might influence future rates of reported hepatitis cases.

\section{Limitations}

This overview has several limitations: first, national surveillance data are limited to reported cases by age, sex and province or territory. It does not provide any risk factor data or differentiate between acute, chronic or reinfection cases. While injection drug use is the most commonly cited risk factor for hepatitis $C$, and thus the focus of this overview, there are other risk factors such as having received care in an hepatitis $\mathrm{C}$-endemic area, other non-injection drug use, needle-stick injury among healthcare workers, having had a blood transfusion before 1992, sex practices that lead to blood exposure, and mother to child transmission (101). Changes associated with any of these risk factors may have also contributed to the observed increase in rates of reported cases from 2014 to 2018. However, there was insufficient literature to determine this. 
Second, Canadian surveillance data do not include the number of people testing for hepatitis $C$, which would inform changes in testing practices over time. Finally, the surveys and papers reviewed used varying time points, and each came with its own set of limitations. For example, the Tracks surveys are crosssectional and descriptive (12).

\section{Conclusion}

The continuous routine and enhanced bio-behavioural surveillance of hepatitis C are crucial for monitoring Canada's hepatitis $C$ epidemic. Improvements to national surveillance data, including collecting risk factor and sociodemographic data and differentiating hepatitis $C$ cases by infection status using standardized national definitions, would improve our understanding of the structural and behavioural risk factors driving HCV transmission in Canada. At the time of developing this overview, PHAC was reviewing the hepatitis $C$ case definition in collaboration with provinces and territories and considering the feasibility of adding a reinfection case definition.

Furthermore, ongoing efforts to strengthen the reach, effectiveness and adoption of evidence-based hepatitis $C$ prevention and treatment services across Canada are vital to reducing HCV transmission among high-risk PWID and achieving Canada's HCV elimination targets by 2030.

\section{Authors' statement}

LL - Conceptualization, research, writing, original draft, final draft, review, editing, supervision

MK-Conceptualization, research, writing, original draft, editing

JT - Editing, research

$\mathrm{KS}$ - Research, editing, reference management

$\mathrm{MB}$ - Review, editing

JA - Conceptualization, review, editing, supervision

\section{Competing interests}

None.

\section{References}

1. Myers RP, Liu M, Shaheen AA. The burden of hepatitis $C$ virus infection is growing: a Canadian population-based study of hospitalizations from 1994 to 2004. Can J Gastroenterol 2008;22(4):381-7. DOI PubMed

2. Myers RP, Krajden M, Bilodeau M, Kaita K, Marotta $P$, Peltekian K, Ramji A, Estes C, Razavi H, Sherman M. Burden of disease and cost of chronic hepatitis $C$ infection in Canada. Can J Gastroenterol Hepatol 2014;28(5):243-50. DOI PubMed

3. Schanzer DL, Paquette D, Lix LM. Historical trends and projected hospital admissions for chronic hepatitis $C$ infection in Canada: a birth cohort analysis. CMAJ Open 2014;2(3):E139-44. DOI PubMed
4. Public Health Agency of Canada. Infographic: people living with hepatitis C (HCV), Canada, 2017. Ottawa (ON): PHAC; 2020 (accessed 2021-08-25). https://www.canada.ca/en/ public-health/services/publications/diseases-conditions/ infographic-people-living-with-hepatitis-c-2017.html

5. Public Health Agency of Canada. Reducing the health impact of sexually transmitted and blood-borne infections in Canada by 2030: a pan-Canadian STBBI framework for action. Ottawa (ON): PHAC; 2018 (accessed 2021-04-20). https://www.canada.ca/en/public-health/services/infectiousdiseases/sexual-health-sexually-transmitted-infections/ reports-publications/sexually-transmitted-blood-borneinfections-action-framework.html

6. Public Health Agency of Canada. Report on hepatitis B and C in Canada: 2018. Ottawa (ON): PHAC; 2021 (accessed 2021-06-28). https://www.canada.ca/en/public-health/ services/publications/diseases-conditions/report-hepatitis-bc-canada-2018.html

7. Health Canada. Fifth Report on Human Biomonitoring of Environmental Chemicals in Canada: Results of the Canadian Health Measures Survey Cycle 5 (2016-2017). Ottawa (ON): HC; 2019 (accessed 2021-06-28). https://www.canada.ca/ en/health-canada/services/environmental-workplace-health/ reports-publications/environmental-contaminants/fifthreport-human-biomonitoring.html

8. Yang Q, Ogunnaike-Cooke S, Halverson J, Yan P, Zhang F, Tomas K, Schanzer D, Archibald CP. Estimated national HIV incidence rates among key subpopulations in Canada, 2014. Presented at 25th Annual Canadian Conference on HIV/AIDS Research (CAHR), 12-15 May 2016, Winnipeg, Canada. Abstract EPH3.5; 2016. https://www.cahr-acrv.ca/ wp-content/uploads/2015/10/CAHR16-Abstracts-for-webFinal.pdf

9. Remis R. Modelling the incidence and prevalence of hepatitis $C$ infection and its sequelae in Canada, 2007: final report. Ottawa (ON): Public Health Agency of Canada; 2009. https://www.phac-aspc.gc.ca/sti-its-surv-epi/model/pdf/ model07-eng.pdf

10. Public Health Agency of Canada. Epidemiology of acute hepatitis $C$ infection in Canada. Results from the Enhanced Hepatitis Strain Surveillance System (EHSSS). Ottawa (ON): PHAC; 2009. https://publications.gc.ca/collections/ collection_2011/aspc-phac/HP40-41-2010-eng.pdf

11. Jacka B, Larney S, Degenhardt L, Janjua N, Høj S, Krajden M, Grebely J, Bruneau J. Prevalence of injecting drug use and coverage of interventions to prevent HIV and hepatitis $C$ virus infection among people who inject drugs in Canada. Am J Public Health 2020;110(1):45-50.

DOI PubMed

12. Tarasuk J, Zhang J, Lemyre A, Cholette F, Bryson M, Paquette D. National findings from the Tracks survey of people who inject drugs in Canada, Phase 4, 2017-2019. Can Commun Dis Rep 2020;46(5):138-48. DOI

13. McNeil R, Shannon K, Shaver L, Kerr T, Small W. Negotiating place and gendered violence in Canada's largest open drug scene. Int J Drug Policy 2014;25(3):608-15. DOI PubMed 
14. Strike C, Rudzinski K, Patterson J, Millson M. Frequent food insecurity among injection drug users: correlates and concerns. BMC Public Health 2012;12:1058. DOI PubMed

15. Schmitz J, Kral AH, Chu D, Wenger LD, Bluthenthal RN. Food insecurity among people who inject drugs in Los Angeles and San Francisco. Public Health Nutr 2016;19(12):2204-12. DOI PubMed

16. Kouyoumdjian F, Schuler A, Matheson FI, Hwang SW. Health status of prisoners in Canada: narrative review. Can Fam Physician 2016;62(3):215-22. PubMed

17. Galea S, Vlahov D. Social determinants and the health of drug users: socioeconomic status, homelessness, and incarceration. Public Health Rep 2002;117 Suppl 1:S135-45. PubMed

18. Arum C, Fraser $H$, Artenie AA, Bivegete $S$, Trickey A, Alary M, Astemborski J, Iversen J, Lim AG, MacGregor L, Morris M, Ong JJ, Platt L, Sack-Davis R, van Santen DK, Solomon SS, Sypsa V, Valencia J, Van Den Boom W, Walker JG, Ward Z, Stone J, Vickerman P; Homelessness, HIV, and HCV Review Collaborative Group. Homelessness, unstable housing, and risk of HIV and hepatitis C virus acquisition among people who inject drugs: a systematic review and meta-analysis. Lancet Public Health 2021;6(5):e309-23. DOI PubMed

19. Morris MD, Yen IH, Shiboski S, Evans JL, Page K. Housing stability and hepatitis $C$ Infection for young adults who inject drugs: examining the relationship of consistent and intermittent housing status on HCV infection risk. J Urban Health 2020;97(6):831-44. DOI PubMed

20. Artenie AA, Fortier E, Sylvestre MP, Høj SB, Minoyan N, Gauvin L, Jutras-Aswad D, Bruneau J. Socioeconomic stability is associated with lower injection frequency among people with distinct trajectories of injection drug use. Int J Drug Policy 2021;94:103205. DOI PubMed

21. Hadland SE, DeBeck K, Kerr T, Feng C, Montaner JS, Wood E. Prescription opioid injection and risk of hepatitis $C$ in relation to traditional drugs of misuse in a prospective cohort of street youth. BMJ Open 2014;4(7):e005419. DOI PubMed

22. Kim C, Kerr T, Li K, Zhang R, Tyndall MW, Montaner JS, Wood E. Unstable housing and hepatitis $C$ incidence among injection drug users in a Canadian setting. BMC Public Health 2009;9:270. DOI PubMed

23. Richardson L, DeBeck K, Feng C, Kerr T, Wood E. Employment and risk of injection drug use initiation among street involved youth in Canadian setting. Prev Med 2014;66:56-9. DOI PubMed

24. Fischer B, Haydon E, Rehm J, Krajden M, Reimer J. Injection drug use and the hepatitis $C$ virus: considerations for $a$ targeted treatment approach--the case study of Canada. J Urban Health 2004;81(3):428-47. DOI PubMed

25. Tarasuk J, Ogunnaike-Cooke S, Archibald C, MacLean R, Bennett R, Kim J, Malloch L; I-Track Principal Investigators. Key findings from a national enhanced HIV surveillance system: 2010 - 2012. Can Commun Dis Rep 2014;40(18):397-407. DOI PubMed
26. Jongbloed K, Pearce ME, Pooyak S, Zamar D, Thomas V, Demerais L, Christian WM, Henderson E, Sharma R, Blair AH, Yoshida EM, Schechter MT, Spittal PM; Cedar Project Partnership. The Cedar Project: mortality among young Indigenous people who use drugs in British Columbia. CMAJ 2017;189(44):E1352-9. DOI PubMed

27. Craib KJ, Spittal PM, Patel SH, Christian WM, Moniruzzaman A, Pearce ME, Demerais L, Sherlock C, Schechter MT; Cedar Project Partnership. Prevalence and incidence of hepatitis $C$ virus infection among Aboriginal young people who use drugs: results from the Cedar Project. Open Med 2009;3(4):e220-7. PubMed

28. Spittal PM, Pearce ME, Chavoshi N, Christian WM, Moniruzzaman A, Teegee M, Schechter MT. The Cedar Project: high incidence of HCV infections in a longitudinal study of young Aboriginal people who use drugs in two Canadian cities. BMC Public Health 2012;12(1):632. DOI PubMed

29. Gordon J, Bocking N, Pouteau K, Farrell T, Ryan G, Kelly L. First Nations hepatitis $C$ virus infections: six-year retrospective study of on-reserve rates of newly reported infections in northwestern Ontario. Can Fam Physician 2017;63(11):e488-94. PubMed

30. Public Health Agency of Canada. Hepatitis $C$ in Canada: 2005-2010 Surveillance report. Ottawa (ON): PHAC; 2011 (accessed 2020-10-27). https://www.catie.ca/sites/default/ files/1109-0139-Hep\%20C\%20Report-FR\%20FINAL.pdf

31. Trubnikov M, Yan P, Archibald C. Estimated prevalence of hepatitis C virus infection in Canada, 2011. Can Commun Dis Rep 2014;40(19):429-36. DOI PubMed

32. Uhanova J, Tate RB, Tataryn DJ, Minuk GY. The epidemiology of hepatitis $C$ in a Canadian Indigenous population. Can J Gastroenterol 2013;27(6):336-40. DOl PubMed

33. The Canadian Network on Hepatitis C. Blueprint to inform hepatitis $C$ elimination efforts in Canada. Montréal ( $Q C)$ : CanHepC; 2019 (accessed 2020-10-25). www.canhepc.ca/ en/blueprint/publication

34. Lanièce Delaunay C, Cox J, Klein M, Lambert G, Grace D, Lachowsky NJ, Maheu-Giroux M. Trends in hepatitis C virus seroprevalence and associated risk factors among men who have sex with men in Montréal: results from three cross-sectional studies (2005, 2009, 2018). Sex Transm Infect 2021;97(4):290-6. DOI PubMed

35. Public Health Agency of Canada. M-Track enhanced surveillance of HIV, sexually transmitted and blood-borne infections, and associated risk behaviours among men who have sex with men in Canada. Ottawa (ON): PHAC; 2011. http://librarypdf.catie.ca/ATI-20000s/26403.pdf 
36. Lockart I, Matthews GV, Danta M. Sexually transmitted hepatitis $C$ infection: the evolving epidemic in HIV-positive and HIV-negative MSM. Curr Opin Infect Dis 2019;32(1):31-7. DOI PubMed

37. van de Laar T, Pybus O, Bruisten S, Brown D, Nelson M, Bhagani S, Vogel M, Baumgarten A, Chaix ML, Fisher M, Gotz H, Matthews GV, Neifer S, White P, Rawlinson W, Pol S, Rockstroh J, Coutinho R, Dore GJ, Dusheiko GM, Danta M. Evidence of a large, international network of HCV transmission in HIV-positive men who have sex with men. Gastroenterology 2009;136(5):1609-17. DOI PubMed

38. Jordan AE, Perlman DC, Neurer J, Smith DJ, Des Jarlais DC, Hagan $H$. Prevalence of hepatitis $C$ virus infection among $\mathrm{HIV}+$ men who have sex with men: a systematic review and meta-analysis. Int J STD AIDS 2017;28(2):145-59.

DOI PubMed

39. Gomes T, Greaves S, Tadrous M, Mamdani MM, Paterson JM, Juurlink DN. Measuring the burden of opioid-related mortality in Ontario, Canada. J Addict Med 2018;12(5):418-9. DOI PubMed

40. Fischer B, O'Keefe-Markman C, Lee AM, Daldegan-Bueno D. 'Resurgent', 'twin' or 'silent' epidemic? A select data overview and observations on increasing psycho-stimulant use and harms in North America. Subst Abuse Treat Prev Policy 2021;16(1):17. DOI PubMed

41. Bruneau J, Roy E, Arruda N, Zang G, Jutras-Aswad D. The rising prevalence of prescription opioid injection and its association with hepatitis $C$ incidence among street-drug users. Addiction 2012;107(7):1318-27. DOI PubMed

42. Roy É, Arruda N, Leclerc P, Morissette C, Blanchette C, Blouin K, Alary M. Drug use practices among people who inject drugs in a context of drug market changes: challenges for optimal coverage of harm reduction programs. Int J Drug Policy 2017;45:18-24. DOI PubMed

43. Bruneau J, Arruda N, Zang G, Jutras-Aswad D, Roy É. The evolving drug epidemic of prescription opioid injection and its association with HCV transmission among people who inject drugs in Montréal, Canada. Addiction 2019;114(2):366-73. DOl PubMed

44. Roy E, Arruda N, Bourgois P. The growing popularity of prescription opioid injection in downtown Montréal: new challenges for harm reduction. Subst Use Misuse 2011;46(9):1142-50. DOI PubMed

45. Bluthenthal RN, Wenger L, Chu D, Bourgois $P$, Kral AH. Drug use generations and patterns of injection drug use: birth cohort differences among people who inject drugs in Los Angeles and San Francisco, California. Drug Alcohol Depend 2017;175:210-8. DOl PubMed

46. Zibbell JE, Asher AK, Patel RC, Kupronis B, lqbal K, Ward JW, Holtzman D. Increases in acute hepatitis C virus infection related to a growing opioid epidemic and associated injection drug use, United States, 2004 to 2014. Am J Public Health 2018;108(2):175-81. DOI PubMed
47. Patrick SW, Bauer AM, Warren MD, Jones TF, Wester C. Hepatitis $C$ virus infection among women giving birthTennessee and United States, 2009-2014. MMWR Morb Mortal Wkly Rep 2017;66(18):470-3. DOI PubMed

48. Koneru A, Nelson N, Hariri S, Canary L, Sanders KJ, Maxwell JF, Huang X, Leake JA, Ward JW, Vellozzi C. Increased hepatitis $C$ virus (HCV) detection in women of childbearing age and potential risk for vertical transmission United States and Kentucky, 2011-2014. MMWR Morb Mortal Wkly Rep 2016;65(28):705-10. DOI PubMed

49. Canadian Centre on Substance Use and Addiction. Methamphetamine. Ottawa (ON): CCSA; 2020 (accessed 2021-06-23). https://www.ccsa.ca/methamphetamine

50. Canadian Centre on Substance Use and Addiction. CCENDU Bulletin: Changes in stimulant use and related harms: focus on methamphetamine and cocaine. Ottawa (ON): CCSA; 2019 (accessed 2021-06-23). https://www. ccsa.ca/changes-stimulant-use-and-related-harms-focusmethamphetamine-and-cocaine-ccendu-bulletin?_cldee $=$ ZWFydGInaWFAdW1 kLmVkdQ\%3D\%3D\&esid=84e16 ab9-8167-e911-a984-000d3af47939\&recipientid=contact8ffdece4f1d1e6118105480fcfeaa931-d091 dbe970d743fe9c200cc95b61d50d

51. Grebely J, Lima VD, Marshall BD, Milloy MJ, DeBeck K, Montaner J, Simo A, Krajden M, Dore GJ, Kerr T, Wood E. Declining incidence of hepatitis $C$ virus infection among people who inject drugs in a Canadian setting, 1996-2012. PLoS One 2014;9(6):e97726. DOI PubMed

52. Cunningham EB, Jacka B, DeBeck K, Applegate TL, Harrigan PR, Krajden M, Marshall BD, Montaner J, Lima VD, Olmstead AD, Milloy MJ, Wood E, Grebely J. Methamphetamine injecting is associated with phylogenetic clustering of hepatitis $C$ virus infection among street-involved youth in Vancouver, Canada. Drug Alcohol Depend 2015;152:272-6. DOI PubMed

53. Scheim Al, Bardwell G, Rachlis B, Mitra S, Kerr T. Syringe sharing among people who inject drugs in London, Canada. Can J Public Health 2018;109(2):174-82. DOI PubMed

54. Tyndall MW, Currie S, Spittal P, Li K, Wood E, O'Shaughnessy MV, Schechter MT. Intensive injection cocaine use as the primary risk factor in the Vancouver HIV-1 epidemic. AIDS 2003;17(6):887-93. DOI PubMed

55. Neufeld J. Plains speak on STBBIs, 2019: an emergent challenge: an emergent challenge for the Prairies. Winnipeg (MB): National Collaborating Centre for Infectious Diseases; 2019 (accessed 2021-05-02). https://nccid.ca/wp-content/ uploads/sites/2/2019/11/Final_Plains-Speak-on-STBBIs-2019Meeting-Proceedings.pdf

56. Drug and Alcohol Testing Association of Canada. Crystal meth use on the rise in the Prairies. Barrie (ON): DATAC; 2018 (accessed 2021-05-05). https://datac.ca/crystal-methuse-on-the-increase-in-the-prairies/ 
57. Keele J. Report finds meth crisis contributing to increase in blood-borne illnesses. CTV News (Winnipeg). Published: 2018-12-11 (accessed 2021-10-27). https://winnipeg. ctvnews.ca/meth-crisis-contributing-to-increase-in-bloodborne-illnesses-report-1.4213562

58. Kusch L, Botelho-Urbanski J. Shared meth syringes drive hepatitis outbreak. Winnipeg Free Press. Posted: 2018-1211. (accessed 2021-02-15). https://www.winnipegfreepress. com/local/lack-of-provincial-leadership-has-exacerbatedcitys-meth-crisis-wrha-charges-in-document-502482181.html

59. Froese I. Meth use in Winnipeg causing outbreak of blood-borne illnesses, new documents say. CBC News (Manitoba). Posted: 2018-12-11 (accessed 2020-10-26). https://www.cbc.ca/news/canada/manitoba/prairie-policemeth-health-disease-1.4941110

60. Pouget ER, Hagan H, Des Jarlais DC. Meta-analysis of hepatitis $C$ seroconversion in relation to shared syringes and drug preparation equipment. Addiction 2012;107(6):1057-65. DOI PubMed

61. Ball LJ, Puka K, Speechley M, Wong R, Hallam B, Wiener JC, Koivu S, Silverman MS. Sharing of injection drug preparation equipment is associated with HIV infection: a cross-sectional study. J Acquir Immune Defic Syndr 2019;81(4):e99-103. DOI PubMed

62. Zibbell JE, Hart-Malloy R, Barry J, Fan L, Flanigan C. Risk factors for $\mathrm{HCV}$ infection among young adults in rural New York who inject prescription opioid analgesics. Am J Public Health 2014;104(11):2226-32. DOI PubMed

63. Ball LJ, Venner C, Tirona RG, Arts E, Gupta K, Wiener JC, Koivu S, Silverman MS. Heating injection drug preparation equipment used for opioid injection may reduce HIV transmission associated with sharing equipment. J Acquir Immune Defic Syndr 2019;81(4):e127-34. DOI PubMed

64. Health Canada. Canadian Drugs and Substances Strategy. Ottawa (ON): HC; 2019 (accessed 2021-06-28). https://www.canada.ca/en/health-canada/services/ substance-use/canadian-drugs-substances-strategy.html

65. Health Canada. Canadian Drugs and Substance Strategy. Ottawa (ON): HC; 2016 (accessed 2021-06-28).

https://www.canada.ca/content/dam/hc-sc/healthycanadians/migration/publications/healthy-living-vie-saine/ drugs-substances-strategy-2016-strategie-drogues-autresubstances/alt/pub-eng.pdf

66. Public Health Agency of Canada. Applying for funding under the Harm Reduction Fund (HRF). Ottawa (ON): PHAC; 2021 (accessed 2021-06-28). https://www.canada.ca/en/publichealth/services/funding-opportunities/sexually-transmittedblood-borne-infections/applying-funding-harm-reductionfund.html

67. Socías ME, Ti L, Wood E, Nosova E, Hull M, Hayashi K, Debeck K, Milloy MJ. Disparities in uptake of direct-acting antiviral therapy for hepatitis $C$ among people who inject drugs in a Canadian setting. Liver Int 2019;39(8):1400-7. DOI PubMed
68. Grebely J, Tran L, Degenhardt L, Dowell-Day A, Santo T, Larney S, Hickman M, Vickerman P, French C, Butler K, Gibbs D, Valerio H, Read P, Dore GJ, Hajarizadeh B. Association between opioid agonist therapy and testing, treatment uptake, and treatment outcomes for hepatitis C infection among people who inject drugs: a systematic review and meta-analysis. Clin Infect Dis 2021;73(1):e107-18. DOI PubMed

69. Public Health Agency of Canada. Report on sexually transmitted infections in Canada, 2018. Ottawa (ON): PHAC; 2021 (accessed 2021-06-28). https://www.canada.ca/en/ public-health/services/publications/diseases-conditions/ report-sexually-transmitted-infections-canada-2018.html

70. Haddad N, Weeks A, Robert A, Totten S. HIV in Canada-surveillance report, 2019. Can Commun Dis Rep 2021;47(1):77-86. DOI PubMed

71. Dore GJ, Altice F, Litwin AH, Dalgard O, Gane EJ, Shibolet O, Luetkemeyer A, Nahass R, Peng CY, Conway B, Grebely J, Howe AY, Gendrano IN, Chen E, Huang HC, Dutko FJ, Nickle DC, Nguyen BY, Wahl J, Barr E, Robertson MN, Platt HL; C-EDGE CO-STAR Study Group. C-EDGE CO-STAR Study Group. Elbasvir-grazoprevir to treat hepatitis $C$ virus infection in persons receiving opioid agonist therapy: a randomized trial. Ann Intern Med 2016;165(9):625-34. DOl PubMed

72. Hajarizadeh B, Grebely J, Matthews GV, Martinello M, Dore GJ. Uptake of direct-acting antiviral treatment for chronic hepatitis C in Australia. J Viral Hepat 2018;25(6):640-8. DOI PubMed

73. Grebely J, Dalgard O, Conway B, Cunningham EB, Bruggmann P, Hajarizadeh B, Amin J, Bruneau J, Hellard M, Litwin AH, Marks P, Quiene S, Siriragavan S, Applegate TL, Swan T, Byrne J, Lacalamita M, Dunlop A, Matthews GV, Powis J, Shaw D, Thurnheer MC, Weltman M, Kronborg I, Cooper C, Feld JJ, Fraser C, Dillon JF, Read P, Gane E, Dore GJ; SIMPLIFY Study Group. Sofosbuvir and velpatasvir for hepatitis $C$ virus infection in people with recent injection drug use (SIMPLIFY): an open-label, single-arm, phase 4, multicentre trial. Lancet Gastroenterol Hepatol 2018;3(3):153-61. DOI PubMed

74. Alimohammadi A, Holeksa J, Thiam A, Truong D, Conway B. Real-world efficacy of direct-acting antiviral therapy for $\mathrm{HCV}$ infection affecting people who inject drugs delivered in a multidisciplinary setting. Open Forum Infect Dis 2018;5(6):ofy120. DOI PubMed

75. Mason K, Dodd Z, Guyton M, Tookey P, Lettner B, Matelski J, Sockalingam S, Altenberg J, Powis J. Understanding real-world adherence in the directly acting antiviral era: $A$ prospective evaluation of adherence among people with a history of drug use at a community-based program in Toronto, Canada. Int J Drug Policy 2017;47:202-8. DOl PubMed

76. Read P, Lothian R, Chronister K, Gilliver R, Kearley J, Dore GJ, van Beek I. Delivering direct acting antiviral therapy for hepatitis $C$ to highly marginalised and current drug injecting populations in a targeted primary health care setting. Int J Drug Policy 2017;47:209-15. DOI PubMed 
77. Wilton J, Wong S, Yu A, Ramji A, Cook D, Butt ZA, Alvarez $M$, Binka M, Darvishian $M$, Jeong $D$, Bartlett $S R$, Pearce ME, Adu PA, Yoshida EM, Krajden M, Janjua NZ. Real-world effectiveness of sofosbuvir/velpatasvir for treatment of chronic hepatitis $C$ in British Columbia, Canada: a population-based cohort study. Open Forum Infect Dis 2020;7(3):ofaa055. DOI

78. Martin NK, Hickman M, Hutchinson SJ, Goldberg DJ, Vickerman P. Combination interventions to prevent HCV transmission among people who inject drugs: modeling the impact of antiviral treatment, needle and syringe programs, and opiate substitution therapy. Clin Infect Dis 2013;57 Suppl 2:S39-45. DOI PubMed

79. Cousien A, Leclerc P, Morissette C, Bruneau J, Roy É, Tran VC, Yazdanpanah Y, Cox J. The need for treatment scale-up to impact HCV transmission in people who inject drugs in Montréal, Canada: a modelling study. BMC Infect Dis 2017;17(1):162. DOI PubMed

80. Schanzer D, Pogany L, Aho J, Tomas K, Gale-Rowe M, Kwong JC, Janjua NZ, Feld J. Impact of availability of direct-acting antivirals for hepatitis C on Canadian hospitalization rates, 2012-2016. Can Commun Dis Rep 2018;44(7-8):150-6. DOI PubMed

81. Shah H, Bilodeau M, Burak KW, Cooper C, Klein M, Ramji A, Smyth D, Feld JJ; Canadian Association for the Study of the Liver. The management of chronic hepatitis C: 2018 guideline update from the Canadian Association for the Study of the Liver. CMAJ 2018;190(22):E677-87.

DOI PubMed

82. Bartlett S, Gennip J, Marshall AD, Bonn M, Fuchs D, Yetman G, Butler-McPhee J, Cooper CL, Gallagher L, Kronfli N, Williams S, Bruneau J, Feld JJ, Janjua N, Klein M, Grebely J. Policies for reimbursement of direct-acting antiviral treatment for hepatitis $C$ virus infection in Canada: "A Patchwork Of Obstruction." In: Canadian Liver Meeting 2021; 2021 May 12-15 (accessed 2021-06-28).

https://www.actionhepatitiscanada.ca/ uploads/8/3/3/9/83398604/clm_2021-poster_bartlett_v2.pdf

83. Saeed S, Strumpf E, Moodie EE, Wong L, Cox J, Walmsley S, Tyndall M, Cooper C, Conway B, Hull M, Martel-Laferriere V, Gill J, Wong A, Vachon ML, Klein MB; Canadian Coinfection Cohort Study Investigators. Eliminating structural barriers: the impact of unrestricted access on hepatitis $C$ treatment uptake among people living with human immunodeficiency virus. Clin Infect Dis 2020;71(2):363-71. DOI PubMed

84. Bartlett SR, Yu A, Chapinal N, Rossi C, Butt Z, Wong S, Darvishian M, Gilbert M, Wong J, Binka M, Alvarez M, Tyndall M, Krajden M, Janjua NZ. The population level care cascade for hepatitis $C$ in British Columbia, Canada as of 2018: impact of direct acting antivirals. Liver Int 2019;39(12):2261-72. DOI PubMed

85. Binka M, Janjua NZ, Grebely J, Estes C, Schanzer D, Kwon JA, Shoukry NH, Kwong JC, Razavi H, Feld JJ, Krajden M. Assessment of treatment strategies to achieve hepatitis $C$ elimination in Canada using a validated model. JAMA Netw Open 2020;3(5):e204192. DOI PubMed
86. Jacob J, Ti L, Knight R. Will peer-based interventions improve hepatitis $C$ virus treatment uptake among young people who inject drugs? Can J Public Health 2021;112(3):460-3. DOI PubMed

87. Goodyear T, Ti L, Carrieri P, Small W, Knight R. "Everybody living with a chronic disease is entitled to be cured": challenges and opportunities in scaling up access to direct-acting antiviral hepatitis $C$ virus treatment among people who inject drugs. Int J Drug Policy 2020;81:102766. DOI PubMed

88. Hajarizadeh B, Grebely J, Martinello M, Matthews GV, Lloyd AR, Dore GJ. Hepatitis C treatment as prevention: evidence, feasibility, and challenges. Lancet Gastroenterol Hepatol 2016;1(4):317-27. DOI PubMed

89. Simmons B, Saleem J, Hill A, Riley RD, Cooke GS. Risk of late relapse or reinfection with hepatitis $C$ virus after achieving a sustained virological response: a systematic review and meta-analysis. Clin Infect Dis 2016;62(6):683-94. DOI PubMed

90. Rossi C, Butt ZA, Wong S, Buxton JA, Islam N, Yu A, Darvishian M, Gilbert M, Wong J, Chapinal N, Binka M, Alvarez M, Tyndall MW, Krajden M, Janjua NZ; BC Hepatitis Testers Cohort Team. Hepatitis $C$ virus reinfection after successful treatment with direct-acting antiviral therapy in a large population-based cohort. J Hepatol 2018;69(5):1007-14. DOl PubMed

91. Hajarizadeh $B$, Cunningham EB, Valerio $H$, Martinello $M$, Law M, Janjua NZ, Midgard H, Dalgard O, Dillon J, Hickman M, Bruneau J, Dore GJ, Grebely J. Hepatitis $C$ reinfection after successful antiviral treatment among people who inject drugs: A meta-analysis. J Hepatol 2020;72(4):643-57. DOl PubMed

92. Public Health Agency of Canada. How has COVID-19 Impacts on the delivery of STBBI-related services, including harm reduction services. Ottawa (ON): PHAC; 2021 (accessed 2021-05-05). https://health-infobase.canada.ca/ datalab/covid-19-impact-stbbi-services.html

93. Canadian Centre on Substance Use and Addiction. Impacts of the COVID-19 pandemic on substance use treatment capacity in Canada. Ottawa (ON): CCSA; 2020 (accessed 2021-06-23). https://www.ccsa.ca/sites/ default/files/2020-12/CCSA-COVID-19-Impacts-PandemicSubstance-Use-Treatment-Capacity-Canada-2020-en.pdf

94. Canadian Centre on Substance Use and Addiction. Impacts of the COVID-19 pandemic on people who use substances: what we heard. Ottawa (ON): CCSA; 2020 (accessed 2021-06-23). https://www.ccsa.ca/sites/default/ files/2020-07/CCSA-COVID-19-Impacts-on-People-WhoUse-Substances-Report-2020-en.pdf

95. Canadian Centre on Substance Use and Addiction. CCENDU Alert: Changes related to COVID-19 in the illegal drug supply and access to services, and resulting health harms. Ottawa (ON): CCSA; 2020 (accessed 2021-06-23). https://www.ccsa.ca/sites/default/files/2020-05/CCSACOVID-19-CCENDU-IIlegal-Drug-Supply-Alert-2020-en.pdf 
96. Friesen EL, Kurdyak PA, Gomes T, Kolla G, Leece P, Zhu L, Toombs E, O'Neill B, Stall NM, Jüni $P$, Mushquash CJ, Mah L; Ontario COVID-19 Science Advisory Table and the Mental Health Working Group. The impact of the COVID-19 pandemic on opioid-related harm in Ontario. Science Briefs of the Ontario COVID-19 Science Advisory Table. 2021;2(42). DOI

97. Reynolds C. Drug users at greater risk of dying as services scale back in second wave of COVID-19. CTV News (Ottawa). 2021 Jan 24 (accessed 2021-10-22).

https://www.ctvnews.ca/health/coronavirus/drug-users-atgreater-risk-of-dying-as-services-scale-back-in-second-waveof-covid-19-1.5279930

98. Lanièce Delaunay $C$, Greenwald ZR, Minoyan N, Artenie AA, Jeong D, Marathe G, Saeed YA, Kolla G, Kunden RD,

Okwor $\mathrm{Cl}$, Wallace HL, Mendlowitz A, Liu CH, Mazouz S, D'souza S, Perciani CT, Rheault M, Palmer MA, Palayew A, Abdelnabi MN, Cunningham EB. 2020-2021 trainees of the Canadian Network on Hepatitis C. Striving towards hepatitis C elimination in the era of COVID-19. Can Liver J 2021;4(1):4-7. DOI
99. Lepage C, Garber G, Corrin R, Galanakis C, Leonard L, Cooper $C$. Telemedicine successfully engages marginalized rural hepatitis $C$ patients in curative care. J Assoc Med Microbiol Infect Dis Can 2020;5(2):87-97. DOI

100. Public Health Agency of Canada. Hepatitis C in Canada: 2019 surveillance data. Ottawa (ON): PHAC; 2021 (accessed 2021-07-05). https://www.canada.ca/en/public-health/ services/publications/diseases-conditions/hepatitis-c-2019surveillance-data.html

101. Centers for Disease Control and Prevention. Hepatitis $C$ questions and answers for the public (accessed 2021-10-19). https://www.cdc.gov/hepatitis/hcv/cfaq.htm

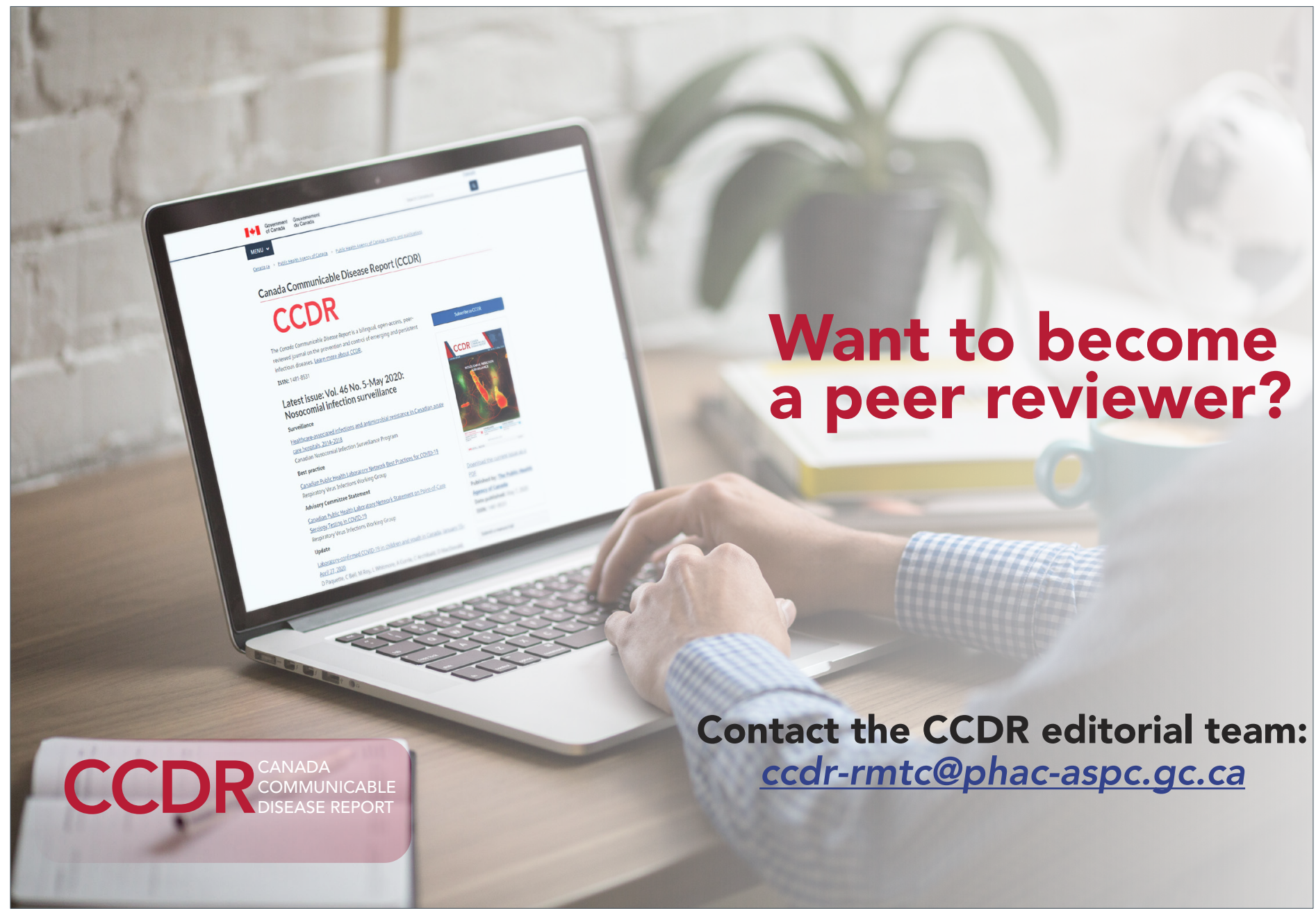

